\title{
Media Exposure to Environmental Health Messages Among Communities in Buton Regency South East Sulawesi province, Indonesia
}

Syahartijan $\mathbf{M L}^{*}$

Department of Social and Political Science, Haluoleo University, Kendari, Indonesia

\begin{abstract}
In general the study to determine the exposure of knowledge on environmental health messages among the communities in Indonesia Specifically, the study to determine the sources of information such as radio, television, and newspaper used to obtain knowledge of environmental health messages among the people in Buton district. The result of the study showed significant difference with reference to the receiving knowledge of environmental health from mass media, in both sub districts. However, the reviving related knowledge of environmental health from television was the most effective way among of sources communication.
\end{abstract}

This indication might explain the ability of mass media, particularly television, in both sub district could increase knowledge of environmental health of the people in Buton Regency generally.

Keywords: Environmental; Health; Television; Communication

\section{Introduction}

The importance of this study can be viewed from both theoretical and practical levels. Theoretically, this study will contribute to an improved understanding of communication media in dissemination environmental health messages especially in the knowledge transfer process of new idea which was proposed by Rogers [1]. Undoubtedly, it will increase better understanding of how media sources are taken into consideration to provide some insight about environmental health issue and will give benefit to the people. Even though this study only involves the environmental health sector in one province, it is believe that it will apply to similar issue relevant to scholars, student, researcher, academic and intellectual discourse and practitioner in communication and rural development elsewhere. There have been many studies about exposure of mass media but studies concerning of environmental health are rare.

Environmental health is important to both developed and developing countries this dependence on environmental health I also reflected in the numerous research and development health programs undertaken by World Health Organization (WHO) and World Bank, as well as governments of the most nations. In order to maximizes the results of health development, the finding of environmental health field from research centre agency should available and disseminated to the community as many users as possible.

\section{Statement of the Problem}

With this scenario especially of communication in Buton regency, this study attempted to answer the following questions.

What are the main sources of information attended by the people to obtain environmental heath messges in Buton regency?

Is there a relationship between exposure of communication in level environmental knowledge health messages in Buton regency?

What are the main environmental health messages utilised by people in Buton regency?

\section{Objective of the Study}

In general, the purpose of study is to determine the exposure to environmental health messegaes among the people in Buton regency.

\section{Specificaly, the study was aimed:}

To determine television as the sources of information used to obtain knowledge of environmental health messages in Buton regency.

To determine radio as the sources of information used to obtain knowledge of environmental health messages in Buton regency.

To determine newspaper as the sources of information used to obtain knowledge of environmental health messages in Buton regency.

This study, based on the local area of Indonesian situation would recommend a communication strategy for providing information that are needed by the local community. An undertaking such us this would provide government planners, local government units and nongovernment organizations mechanism towards understanding the conditions of community in using communication strategies for better and improved environmental health practices. Moreover, the research could provide policy maker a broader perspective on the kind of health programs most suitable to communicate of Indonesian society.

In this paper, will be presented to analyze the differences of mass media in disseminate of environmental health messages among communities in Indonesia. To find out whether there are significant relationship among mass communication such as radio, television and newspaper to the knowledge of environmental health issue of respondent.

\section{Method}

\section{Selection of respondents}

Both sub disticts population reached 8,436 with their reliability

${ }^{*}$ Corresponding author: Syahartijan ML, Department of Social and Political Science, Haluoleo University, Kendari, Indonesia, Tel: +62 401 3190105; E-mail: syahartijanlaode@gmail.com

Received April 13, 2018; Accepted August 04, 2018; Published August 10, 2018 Citation: Syahartijan ML (2018) Media Exposure to Environmental Health Messages Among Communities in Buton Regency South East Sulawesi province, Indonesia. J Mass Communicat Journalism 8: 381. doi: 10.4172/21657912.1000381

Copyright: $\odot 2018$ Syahartijan ML. This is an open-access article distributed under the terms of the Creative Commons Attribution License, which permits unrestricted use, distribution, and reproduction in any medium, provided the original author and source are credited. 
Citation: Syahartijan ML (2018) Media Exposure to Environmental Health Messages Among Communities in Buton Regency South East Sulawesi province, Indonesia. J Mass Communicat Journalism 8: 381. doi: 10.4172/2165-7912.1000381

Page 2 of 3

level at (10\%). From above computation, a total of 99 respondents were taken from the two sub district of Kapuntori and Wabula.

Personal interview with the use of a structure questionsmaire were conducted to gater information from respondent. The study covered household with requirenment sex, 20-64 hiears and qualified senior high school graduates respondent were selected through systematic random sampling.

The study were hypothesizes as the following assumptions:

There is significantly different between listening radio by knowledge of environmental health messanges of respondent.

There is significantly different between wacthing television by knowledge of environmental health messages of respondent.

There is significantly different between reading newspaper by knowledge of environmental health messages of respondent.

The hypotesis was analized by statistical analisis system (SAS) version 6.12. anova analisis to explain whether there are significant variation among information the knowledge of environmental health issues (dependent variable) of respondent in both area of study. And afterwards the significant variation analyzed by duncan's multiple range test (DMRT). Significant level of this study to test those varible is 0.05 (Figure 1 ).

Table 1 shows that media variabel is singnificant, then this variabel was analyzed

By Duncan,s multiple range Test (DMRT)
The mass communication can be assumed as having the linear model as

Follows:

Yijkm=M+Ii+DJ+Eklj+I Etk (j)+Em (ijk)

Where $\mathrm{M}$ mean average

Mi is Media, i 1,2,3, (TV, Radio, Newspapers)

$D j$ is District, $\mathrm{j}=1,2$ (Mandoga and soropia).

(Eklj) is Environmental Health messages (ENHAM) within District, $\mathrm{K}=1,2,3,4$

(Clean Safe water, proper Garbage Disposal, Dwelling Unit House, sanitary Toilet)

For all $\mathrm{j}$.

Em (ijk) is random error, $m=1,2,3$, all $i, j, k$.

By using Statistic Analytical System (SAS) Software to calculate the anova the result is shown in Table 1 . The assumption additive modal of eqn. (1) Was the giving the R - Square of 0.943308 with Coefficient of variant (CV) 26.84855. This mean that the assumption of additive modal is carrect later, the media variable was significantly different. The duncan multiple range test show the result on the Table 2 . The result of the duncan's multiple range test as follow.

Table 2 shows that there was significant difference between television, radio and newspaper to The mass communication for

\section{Conceptual framework of the study}
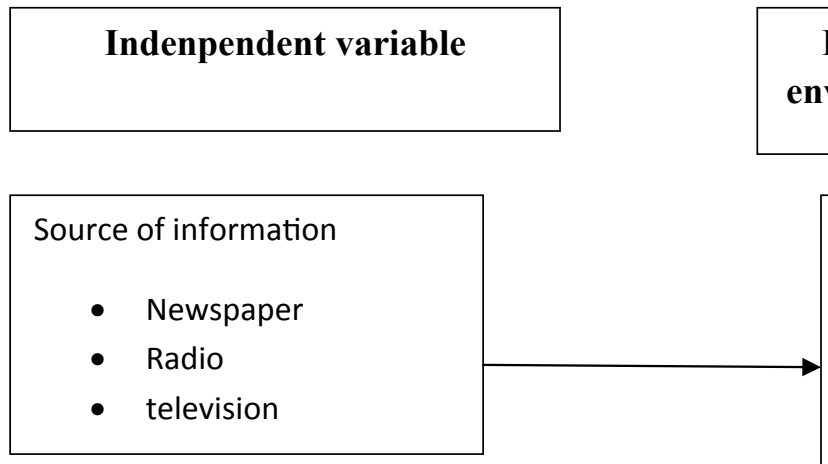

\section{Dependent variable Level of environmental health knowledge}

Environmental health

- Clean water

- Garbage disposal

- Health house

- Sanitary toilets

Figure 1: Conceptual framework showing, linkages between mass media to the knowledge of environmental health issues.

\begin{tabular}{|c|c|c|c|c|}
\hline Sources of variance & DF & Sum of squares & Mean value & Fr value \\
\hline Media & 2 & 2799,250 & 1399.6250 & 71.35 \\
\hline Dist. (district) & 1 & 0.68 & 0.68 & 0.03 \\
\hline Enham & 3 & 0.0 & 0.0 & 0.01 \\
\hline Enham (Dist.) & 3 & 0.0 & 0.0 & 0.0 \\
\hline Media (Dist.) & 2 & 1118.583 & 559.292 & 28.50 \\
\hline Error & 12 & 235.50 & 1.0 & \\
\hline Corrected Total & 23 & 4154.00 & & \\
\hline
\end{tabular}

R-Square $=0.943308$

$C V=26.84855$.

Tabel 1: Analysis of variance mass communication. 


\begin{tabular}{|c|c|}
\hline Mass Media & Means \\
\hline Television & $31.125 \mathrm{~A}$ \\
\hline Radio & $13.000 \mathrm{~B}$ \\
\hline Newspaper & $5.375 \mathrm{C}$ \\
\hline
\end{tabular}

Table 2: Duncan's multiple range tests for mass communication to the knowledge of environmental health messages of respondents in both sub districts.

respondent to receive environmental health issue. Television was the most superior followend by radio and newspaper. This indicate that among mass communication, television is the mots successful medium in term of Receiving envirenmental health messages from mass media followed by radio and newspaper.

\section{Discussion}

Based on review from the frevious study, it was hypodiestsed that there are significant differences between mass media to the knowledge of envirdan health of respondent both sub-districk Table 2 reveals that there was a substanal significant differences among mass communication with knowlodge of envirenmental health messages of respondent both sub-districk. That, the hypotesis was accepted the resuld suggested that the respondent who watch television would more aware for the environmental health messages that people whe just listen to radio or simply read newspaper. The result of this sudy of supported by rogers [1] on "diffusion and innovation" which stated, that television are more effective in spreading knowledge of innovations. The modern healt communication campaiga use a variety of approaches to deliver health messages to their targeted audiences including multiply media, in conjunction with community-based and intrpersonal metheds of messages delivery and promotion of knowlodge, attitudes, or and change. Similar study from atkin and arkin that awarenes and attitudes changes can be affected by health communication, inclading various aspects of a peson's health-related beliefs, such as perception of risk probabilities and acquisition of knowledge related to problem solving. Herianto [2] conducted study in malaysia stated that people who are intensively exposed to the media will achieve more knowledge, positive attitude and also beact implementation [3].

The references postulated, that the mass media hass immediate and powerful effect on mass audience to the community. Mass media such as, radio, TV and newspaper can not direatly inflance attitudes and behavior, due to the feedback of mass media is not dircetly perceifed quikly by audiences [4]. Interpersonal channel (e.g., family, friends, community, influential) are more effective at changing attitudes, behavior toward innovations and eventually getting people to adopt them. Personal contact is even more important to adoption when the innovation is complicated to use or when its benefid are not immeditely apparent [5].

This result in compliance with reality that, mass media more effective to disseminate new idea in terms of enveronmental health knowledge to the respondent. Particularly television is the most effective way to receive the environmental health messages. New spaper was medi which respondent getting in touch between newspaper (the least frequent) and television (the most frequent) [6-8].

\section{Conclusions}

From the finding of the studi, the following conclusions were drawn:

Television is the most frequent media taken by the respondent as a source of knowledge in environmental health. Newspaper was the media which the respondents getting in touch less. Radio was the source of information wich respondent getting in touch between newspaper (the least frequent) and television (the most frequent).

\section{References}

1. Rogers EM (1993) Diffusion and Innovation, New York. The Free Press.

2. Herianto AS ( 2007) The role of Multi - Media in Narrowing The KAP - GAPS Among the farmer of the strategic Extension Campaign in Media Irrigation Scheme.

3. Biagi S (2001) Media Impact: an Introduction to Mass Media. Fifth Edition.

4. Dalmia PH, Ang S (2000) Operational, not theoretical: A critique of the current paradigm in development communication. Asian Journal of Communication 10.

5. Health Department (2008) Community Health Environment. Jakarta.

6. Health Statistic of Buton Regency (2005) Buton Regency Press.

7. Brent R (2014) Communication Theory and Health Communication Practice: The More Things Change, the More They Stay the Same. Health Communication.

8. Griffin RJ, Dunwoody S (2000) The relation of communication to risk Judgement and Preventive Behaviour related to lead in Tap water. Journal Health Communication 12: 81-107. 